DOI:10.22337/2587-9618-2019-15-1-90-97

\title{
BEARING CAPACITY OF DEEP PILE FOUNDATION FOR HIGH-RISE FACILITY ON WEAK SOILS: COMPARING OF ANALYSIS RESULTS AND EXPERIMENTAL DATA
}

\author{
Rashid A. Mangushev ${ }^{1}$, Nadezhda S. Nikitina ${ }^{2}$ \\ ${ }^{1}$ Saint-Petersburg State Architecture and Construction University, Saint-Petersburg, RUSSIA \\ ${ }^{2}$ National Research Moscow State University of Civil Engineering, Moscow, RUSSIA
}

\begin{abstract}
The results of static testing of the pile and comparative results of analytical and numerical calculations for the experimental deep pile (length $65 \mathrm{~m}$, diameter $1.2 \mathrm{~m}$ ) under the high-rise building, designed in the area of a large thickness of weak soils, are presented in the paper. At the same construction site, an experimental barrette pile of rectangular crosssection with a size of $3.3 \times 1.1$ and a length of $65 \mathrm{~m}$ with the location of the base in solid Proterozoic clays was made. This pile was tested with the use of Osterberg cells, for which strain gauges were mounted in its reinforcement cage at 9 levels. In the first stage, a standard test of the entire experimental barrette pile in the top-down direction was conducted; in the second, after reaching the maximum possible load, the tests were carried out using the "O-cells" located at a depth of $50 \mathrm{~m}$ in the thickness of solid clays and transmitting the load in two directions (up and down). A General assessment of the bearing capacity of the barrette pile obtained by three methods is given.
\end{abstract}

Keywords: bearing capacity, analytical methods, numerical methods, experimental studies, pile, high-rise building, weak soils

\section{НЕСУЩАЯ СПОСОБНОСТЬ СВАЙНОГО ФУНДАМЕНТА ГЛУБОКОГО ЗАЛОЖЕНИЯ ДЛЯ ВЫСОТНЫХ ОБЪЕКТОВ НА СЛАБЫХ ГРУНТАХ: СОПОСТАВЛЕНИЕ РЕЗУЛЬТАТОВ РАСЧЕТА И ЭКСПЕРИМЕНТАЛЬНЫХ ДАННЫХ}

\author{
P.А. Мангушев ${ }^{1}$, Н.С. Никитина ${ }^{2}$ \\ ${ }^{1}$ Санкт-Петербургский государственный архитектурно-строительный университет, \\ г. Санкт-Петербург, РОССИЯ \\ ${ }^{2}$ Национальный исследовательский Московский государственный строительный университет, \\ г. Москва, РОССИЯ
}

\begin{abstract}
Аннотация: В настоящей статье представлены результаты статических испытаний и соответствующие сравнительные результаты аналитических и численных расчетов для опытной глубокой сваи (длина - 65 метров, диаметр - 1.2 метра) под высотным зданием, спроектированным в зоне большой толщи слабых грунтов. На той же строительной площадке была изготовлена опытная свая-баретта прямоугольного сечения размером $3.3 \times 1.1$ метра и длиной 65 метров с расположением основания в твердых протерозойских глинах. Эта свая была испытана с использованием ячеек Остерберга. Для этого при устройстве сваи в ее арматурном каркасе были установлены тензодатчики на девяти уровнях. Испытание опытной сваи-баретты проводилось с два этапа. Так, на первом этапе было выполнено стандартное испытание всей сваи в направлении сверху вниз, а на втором этапе, после достижения максимально возможной нагрузки, испытания проводились с использованием ячеек “О-сеll”, которые располагались на глубине 50 метров в толще твердых глин, передающих нагрузку в двух направлениях (вверх и вниз). Дана общая оценка несущей способности сваи-баретты на основе трех методов.
\end{abstract}

Ключевые слова: несущая способность, аналитические методы, численные методы, экспериментальные исследования, свая, высотные здания, слабые грунты 
Bearing Capacity of Deep Pile Foundation for High-Rise Facility on Weak Soils:

Comparing of Analysis Results and Experimental Data

\section{INTRODUCTION}

Modern large-scale underground construction in a cramped town planning and a sharp increase in the number of facilities' storeys requires careful consideration of the pile construction affecting (especially in weak soils) and changes in soil properties directly under the foundation and in the surrounding area under the influence of man-made factors that appear during construction process. It is the most important to consider such changes in complex geotechnical conditions. An important aspect in this case is the assessment of the bearing capacity of piles by analytical methods. Therefore, it is very valuable to compare reliability of such analytical methods with full-scale tests.

A large number of analytical methods for calculating the bearing capacity of a single pile, taking into account pile geometric dimensions and the characteristics of the surrounding soil [1], is known. Unfortunately, often the calculated values differ significantly from the natural ones obtained when loading such piles with vertical load. Especially acute this problem arises with a large length of piles and their production under the protection of a clay mortar or casing pipe. Comparing of the differences between results of calculations for Building Codes of the Russian Federation SNiP 24.13330 [2] and SP 50-1022003 [3] and results of standard tests for vertical load according to Standard of the Russian Federation GOST 5686 [3] show that the first, as a rule, is much smaller for first ones than the second. In addition, the anthropogenic impact on the soil under the foundation can be local and general (territorial) in nature and differs depending on the adopted technology $[1,2]$.

In accordance with the mentioned above, relevant assessments and comparisons carried out with respect to pile foundations of high-rise buildings in the conditions of their construction on weak soils are of interest.

The mentioned problem was investigated during of design work on the building of "Okhta-Center" (height $396 \mathrm{~m}$ ). In order to determine the total bearing capacity of bored piles and barrette piles, as well as, separately of bearing capacity on the lateral surface and the base, two experimental bored piles under the protection of a casing pipe with a diameter of $1.2 \mathrm{~m}$ and a length of $52.8 \mathrm{~m}$ (piles BN), and five experimental barrette piles with a size of $3.3 \times 1.0 \mathrm{~m}$ and a length of $65 \mathrm{~m}$ (piles SB) were built and tested.

\section{ENGINEERING GEOLOGICAL CONDITIONS OF THE TEST SITE}

According to the results of drilling to a depth of $170 \mathrm{~m}$, the ground sediments were revealed at the base, kinds and average characteristics of which are given in the table 1 .

\section{EVALUATION OF BEARING CAPACITY OF EXPERIMENTAL PILE BN}

In accordance with the regulatory documents of the Russian Federation [1,2] the calculated bearing capacity of friction piles is determined by the formula

$$
F_{d}=\gamma_{c}\left[\gamma_{c R} R A+u \sum \gamma_{c f} f_{i} h_{i}\right]
$$

where $\gamma_{c}$ is coefficient of working conditions of a pile in a ground, which takes the value for driving piles $\gamma_{c}=1 ; R$ is design resistance of the soil under the lower end of the pile; $A$ is area of pile cross section, $\mathrm{m}^{2} ; u$ is perimeter of the pile cross section; $f_{i}$ is design resistance of $i$-th soil layer along the lateral surface of the pile, $\mathrm{kPa} ; h_{i}$ is thickness of $i$-th soil layer surrounding the pile surface, $\mathrm{m}$, that should be $h_{i} \leq 2 \mathrm{~m} ; \gamma_{c R}, \gamma_{c f}$ are the coefficients of working conditions of the ground under the lower end of the pile and surround the pile surface respectively which take in account affecting of the pile production technology.

Tests of piles BN were conducted using hydraulic jacks until a maximum load of $3500 \mathrm{~T}$ $(35000 \mathrm{kN}$; Production and testing of bored piles were carried out by the company "Geoizol" in 2009). 
Table 1. Characteristics of soil.

\begin{tabular}{|c|c|c|c|c|c|c|c|c|}
\hline A name of soil & $\begin{array}{l}\text { Geological } \\
\text { index }\end{array}$ & $\begin{array}{c}\gamma, \\
\mathrm{kN} / \mathrm{m}^{3}\end{array}$ & $\mathrm{~W}$ & e & $\mathrm{IL}$ & $\begin{array}{c}\mathrm{E} \\
\mathrm{MPa}\end{array}$ & $\begin{array}{c}\varphi, \\
\text { degree }\end{array}$ & $\begin{array}{c}\mathrm{c}, \\
\mathrm{MPa}\end{array}$ \\
\hline Bulk soil & $\operatorname{tg}$ IV & 17.5 & \\
\hline $\begin{array}{l}\text { Marine and lake } \\
\text { sediments }\end{array}$ & $\mathrm{m}, 1 \mathrm{IV}$ & 19.6 & 0.256 & 0.683 & 0.71 & 14 & 24 & 0 \\
\hline $\begin{array}{l}\text { Upper glacial lake } \\
\text { sediments } \\
\text { (upper sediments) of } \\
\text { the Baltic glacial lake }\end{array}$ & $\lg$ IIIb & 18.6 & 0.360 & 0.980 & 1.1 & 4.5 & 7 & 0.006 \\
\hline $\begin{array}{l}\text { Lower glacial lake } \\
\text { sediments of the } \\
\text { Luga moraine } \\
\text { (lower sediments) }\end{array}$ & $\operatorname{lgIIIz}$ & 20.4 & 0.220 & 0.600 & 0.87 & 10.5 & 17 & 0.030 \\
\hline $\begin{array}{l}\text { Moraine sediments } \\
\text { of the Luga moraine }\end{array}$ & gIIIlz & 21.5 & 0.160 & 0.43 & 0.25 & 17 & 22 & 0.036 \\
\hline $\begin{array}{l}\text { Dislocated Vendian } \\
\text { clays }\end{array}$ & Vkt2 & 21.4 & 0.176 & 0.503 & -0.35 & 16 & 14 & 0.130 \\
\hline $\begin{array}{l}\text { Undislocated } \\
\text { Vendian clays }\end{array}$ & Vkt2 & 22.3 & 0.129 & 0.367 & -0.79 & 113 & 22 & 0.840 \\
\hline
\end{tabular}

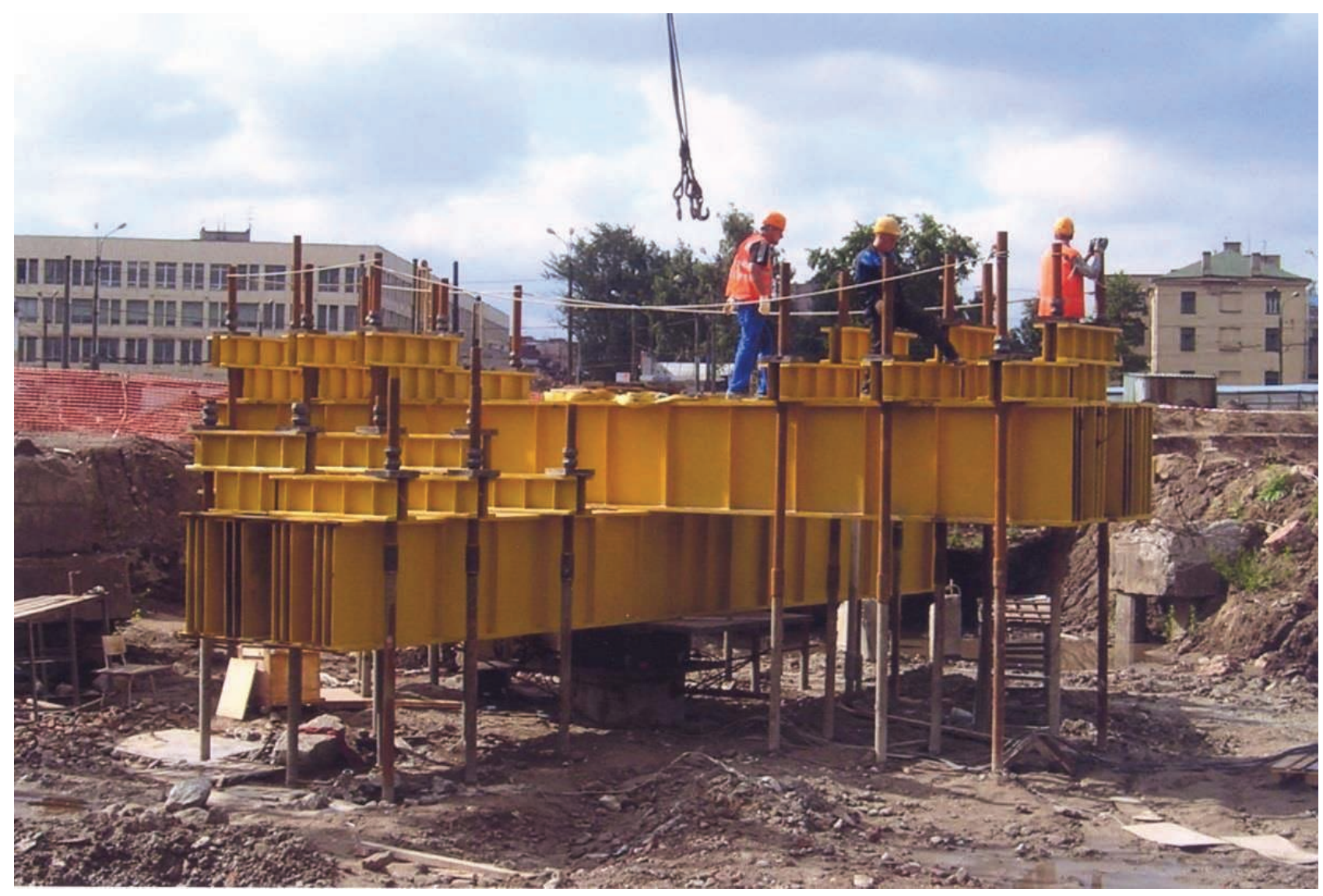

Figure 1. General view of loading system for testing of BN pile under static vertical load. 
Bearing Capacity of Deep Pile Foundation for High-Rise Facility on Weak Soils:

Comparing of Analysis Results and Experimental Data

Table 2. Results of assessment of BN pile overall bearing capacity by different methods.

\begin{tabular}{|l|c|}
\hline $\begin{array}{c}\text { Method for determining the bearing capacity } \\
\text { of a pile }\end{array}$ & $\begin{array}{c}\text { Overall bearing capacity of the } B N \\
\text { experimental pile, } k N\end{array}$ \\
\hline \hline Calculation by the formula $(1), F_{d, \text { calc }}$ & $8320(-301 \%)$ \\
\hline Calculation by PC PLAXIS 3D, $F_{d, P L A X I S}$ & $11000(-227 \%)$ \\
\hline Experimental data, $F_{d, \text { site }}$ & 25000 \\
\hline
\end{tabular}

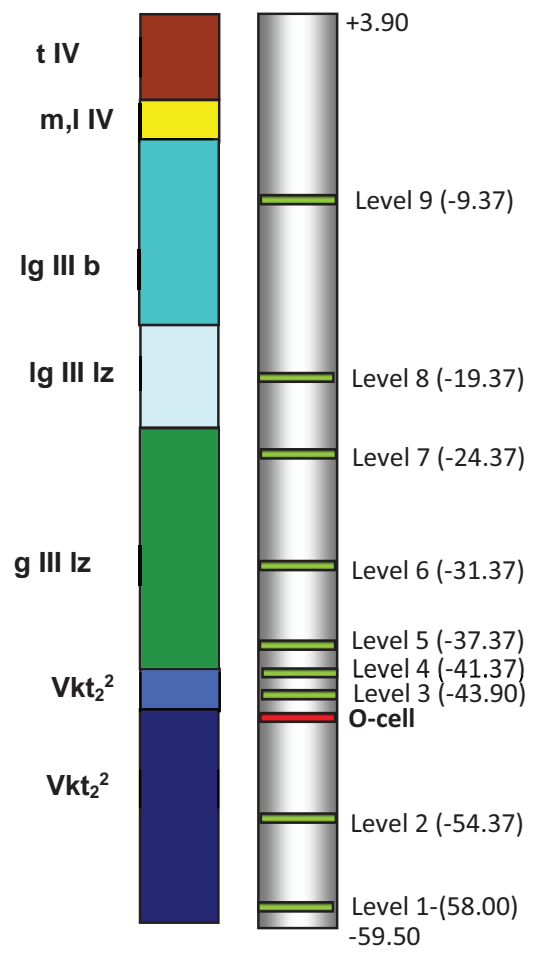

Figure 2. Situation scheme of O-cell element and strain ganges in the experimental barrette pile.

In order to provide these tests, a special loading platform of cross beams, based on a system of 33 drilling-injection anchors of the "Titan" type (Fig. 1), was arranged.

According to [4] the overall pile bearing capacity was assessing by the value of load for which pile gets vertical deformation $\Delta=20 \mathrm{~mm}$ that in the considered case corresponds to loading $F_{d, \text { site }}=$ $25000 \mathrm{kN}$.

Calculation by the formula (1) gave the value of overall bearing capacity of the experimental pile $F_{d, \text { calc }}=8320 \mathrm{kN}$, that includes $5985 \mathrm{kN}(71 \%)$ under the tip and only $3145 \mathrm{kN}(29 \%)$ on the lateral surface.

The value of overall bearing capacity obtained by $[2,3]$ is similar to analysis result of pile under vertical load in PC PLAXIS 3D $\left(F_{d, P L A X I S}=\right.$ $11000 \mathrm{kN})$.
Results of assessment of BN pile overall bearing capacity by different methods are given in table 2.

\section{EVALUATION OF BEARING CAPACITY OF EXPERIMENTAL BARRETTE PILE SB}

At the mentioned building site it was provided experimental testing of barrette pile with length of $65 \mathrm{~m}$ and cross section of $3.3 \times 1.0 \mathrm{~m}$. The pile was immersed into Vendian clays layer (Vkt2). During the tests, it was used Osterberg cells (Ocells) and strain gauges the situation scheme of which is presented in Figure 2. 


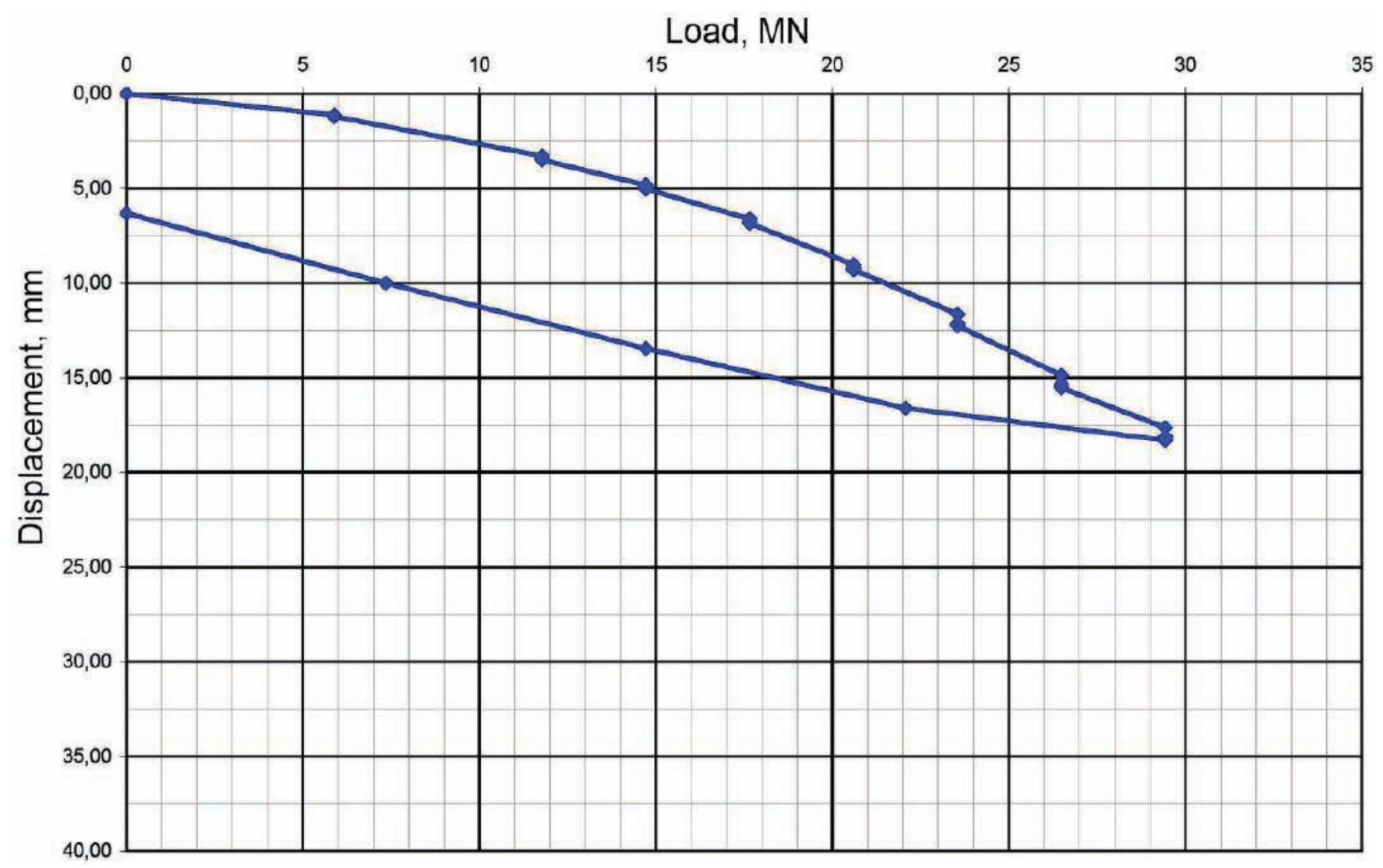

Figure 3. Load-deformation diagram for barrette pile under vertical loading.

Tests of the pile under vertical static load were conducted in two stages: first one is standard test under vertical load applied Top-down; second one is test conducted when load reached its maximum value with usage of $\mathrm{O}$-cell at depth value $-45.00 \mathrm{~m}$. Using $\mathrm{O}$-cell, the loading was transmitted in two direction: up and down [5]. The test results for experimental barrette at first stage by Top-down method are shown in Figure 3. At the maximum load $35000 \mathrm{kN}$ deformation does not exceed $20 \mathrm{~mm}$.

Extrapolation of load-deformation diagram until horizontal line corresponding to $\Delta=20 \mathrm{~mm}$ allows assessing overall bearing capacity of the experimental barrette pile at it first loading by $F_{\text {d,Top-Down }}=32000 \mathrm{kN}$.

An analytical calculation of the experimental barrette pile by the formula (1) $[2,3]$ gives value of the overall bearing capacity $F_{d, \text { calc }}=31244 \mathrm{kN}$, that is enough close to test results obtained by Top-down method.

Calculational results obtained by PC PLAXIS 3D give value of the overall bearing capacity
$F_{d, P L A X I S}=27800 \mathrm{kN}$ (Figure 4) that is smaller than results of Top-down experimental method. The results of the tests using the Osterberg Ocell, performed after the Top-down loading are shown in Figure 5.

The upper curve corresponds to the bottom-up test of the upper part of the pile and makes it possible estimating the bearing capacity of the barrette on the lateral surface; the lower curve reflects the tests from top to bottom of the pile and allows estimating the bearing capacity of the barrette base.

Extrapolation of the upper curve to the intersection with the horizontal axis corresponding to the value of $\Delta=-20 \mathrm{~mm}$ gives the opportunity to evaluate the bearing capacity of the lateral surface of pile $F_{d}{ }^{f}$,o-cell $=29500 \mathrm{kN}$, and the bottom graph allows evaluating the bearing capacity under the tip of barrett which is not less than $F_{d}{ }^{R}{ }_{\text {,o-cell }}=13000 \mathrm{kN}$. The total bearing capacity of the pile according to the described test method is not less than $F_{d, o-c e l l}=$ $42500 \mathrm{kN}$. 
Bearing Capacity of Deep Pile Foundation for High-Rise Facility on Weak Soils:

Comparing of Analysis Results and Experimental Data

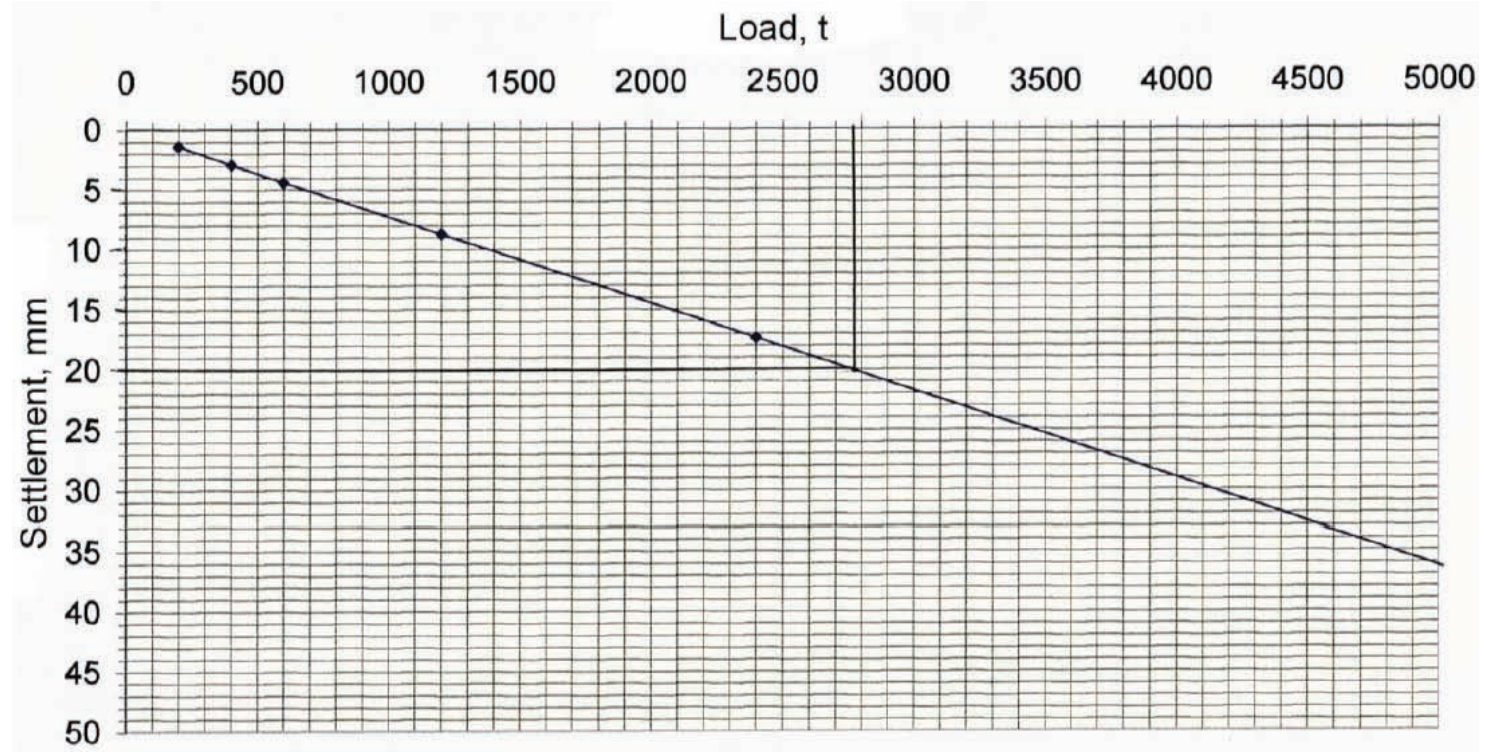

Figure 4. Calculational results obtained by PC PLAXIS 3D for experimental barrette pile under vertical loading.

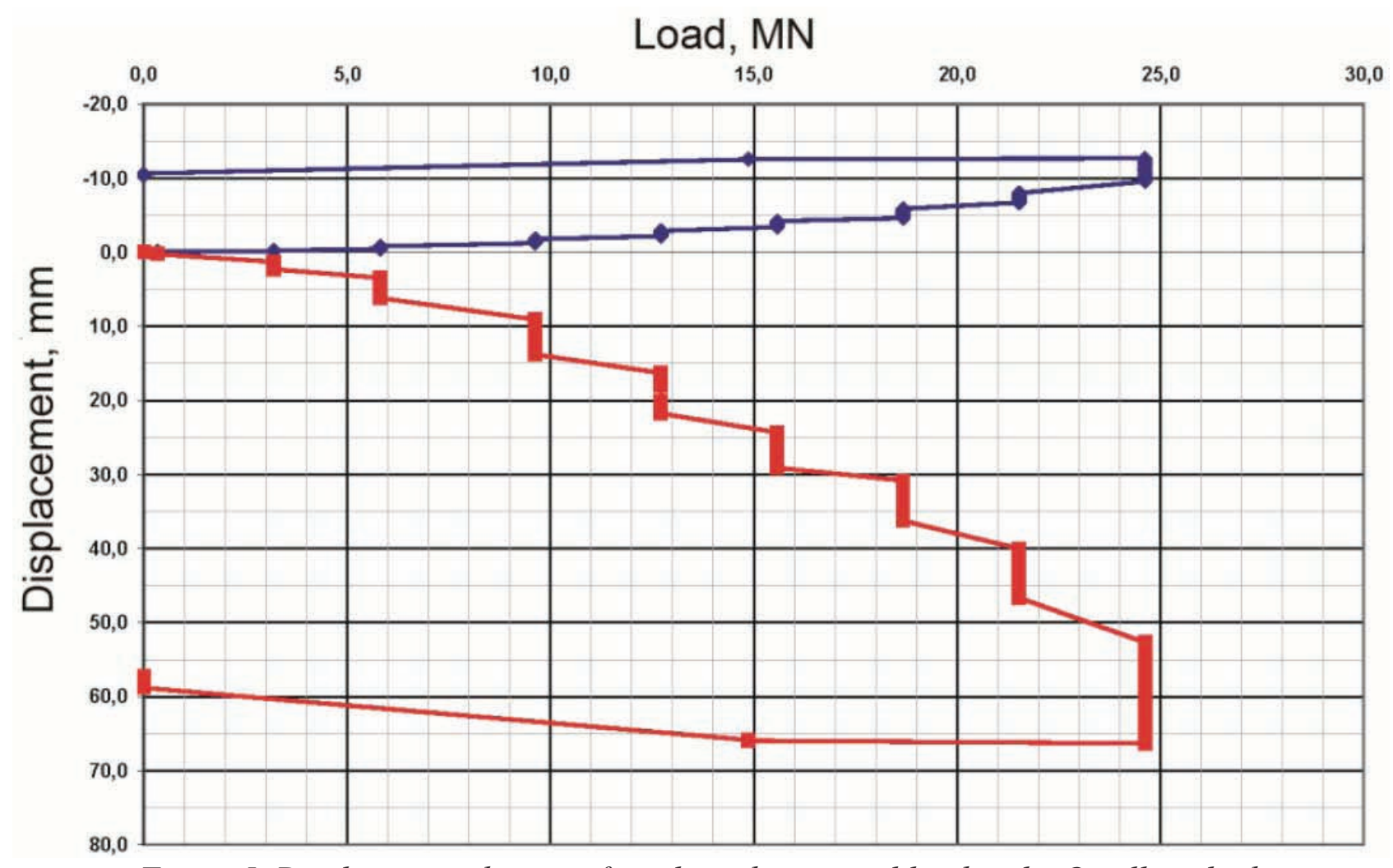

Figure 5. Displacement diagram for pile under vertical loading by $O$-cell method.

As expected, the total bearing capacity of the barrette pile under repeated loading by the "Ocell" method is higher than under primary loading by the "Top-down" method (more than $30 \%)$.
Table 3 summarizes the test results by the method of "O-cell" and analytical calculations of bearing capacity of the barrette piles. 
Table 3. Summary of test results by the method of "O-cell" and analytical calculations of bearing capacity of the barrette piles.

\begin{tabular}{|l|c|}
\hline \multicolumn{1}{|c|}{$\begin{array}{c}\text { Method of bearing capacity } \\
\text { determining for barrette pile }\end{array}$} & $\begin{array}{c}\text { Total of bearing capacity of the } \\
\text { experimental barrette pile } F_{d}, \kappa H\end{array}$ \\
\hline \hline Calculation by the formula (1), $F_{d, \text { calc }}$ & $31244(-2,5 \%)$ \\
\hline Calculation by PLAXIS 3D, $F_{d, P L A X I S}$ & $27800(-15 \%)$ \\
\hline $\begin{array}{l}\text { Natural tests' result by Top-Down method } \\
\text { (primary loading), } F_{d, T o p-D o w n}\end{array}$ & 32000 \\
\hline $\begin{array}{l}\text { Natural tests' result «O-cell» method } \\
\text { (secondary loading), }\end{array}$ \\
$F_{d, \text { o-cell }}$ & 42500 \\
$F_{d}^{f}$, o-cell & 29500 \\
$F_{d}{ }^{R}$, o-cell & 13000 \\
\hline
\end{tabular}

\section{CONCLUSIONS}

1. The bearing capacity of the experimental piles with a diameter of $1.2 \mathrm{~m}$ and a length of 52.8 $\mathrm{m}$ according to the test results is significantly higher (more than 200\%) than the calculated values according to Russian standards $[2,3]$ and the PLAXIS 3D program.

2. The bearing capacity of the experimental pilebarrette with a length of $65 \mathrm{~m}$ and a cross section of $3.3 \times 1.0 \mathrm{~m}$ according to the results of full-scale tests is very close to the calculated values according to Russian standards [1,2] (deviation of 2,5\%) and the program PLAXIS 3D (deviation of 15\%).

3. The bearing capacity of the soil on the tip $(13000 \mathrm{kN})$ equals half value of one's on the lateral surface $(29000 \mathrm{kN})$, despite the presence of a large thickness of weak soils along the trunk of the barrette pile.

\section{REFERENCES}

1. Mangushev R.A., Gotman A.L., Znamenskiy V.V., Ponomarev A.B. Svai i Svaynyye Fundamenty. Konstruktsii, Proyektirovaniye i Tekhnologii [Piles and pile Foundations. Constructions, Design and Technology]. Moscow, ASV Publishing House, 2015, 320 pages (in Russian).

2. Building Code of the Russian Federation SNiP 24.13330.2011. Svod Pravil.
Svaynyye fundamenty. Aktualizirovannaya Redaktsiya SNiP 2.02.03-85 [Pile Foundations. Updated Version of SNiP 2.02.03-85] (in Russian).

3. Building Code of the Russian Federation SP 50-102-2003. Proyektirovaniye i ustroystvo svaynykh fundamentov [Design and Installation of Pile Foundations] (in Russian).

4. Standard of the Russian Federation GOST 5686-2012. Grunty. Metody polevykh ispytaniy svayami [Soils. Field Test Methods by Piles] (in Russian).

5. Kolodiy Ye.V. Sravnitel'nyy analiz sovremennykh metodov otsenki nesushchey sposobnosti svay (na primere svai-baretty $\mathrm{v}$ inzhenerno-geologicheskikh usloviyakh Sankt-Peterburga) [Comparative analysis of modern methods for assessing the carrying capacity of piles (using the example of a pile-barette in the engineering-geological conditions of St. Petersburg)]. // Sb. trudov nauchn.-tekhn. konferentsii «Aktual'nyye voprosy geotekhniki pri reshenii slozhnykh zadach novogo stroitel'stva i rekonstruktsii» [Proc. of scientific and technical conf. Actual issues of geotechnics in solving complex problems of new construction and reconstruction"], SPbGASU, Saint Petersburg, 2010. Pp. 87-95 (in Russian). 
Bearing Capacity of Deep Pile Foundation for High-Rise Facility on Weak Soils:

Comparing of Analysis Results and Experimental Data

\section{СПИСОК ЛИТЕРАТУРЫ}

1. Мангушев Р.А., Готман А.Л., Знаменский В.В., Пономарев А.Б. Сваи и свайные фундаменты. Конструкции, проектирование и технологии. - М.: АСВ, 2015. $-320 \mathrm{c}$.

2. СНиП 24.13330.2011. Свод правил. Свайные фундаменты.

Актуализированная редакция СНиП 2.02.03-85. Утв. Приказом Минрегиона РФ от 29.12.2011. № 635/2.

3. 3. СП 50-102-2003. Проектирование и устройство свайных фундаментов. - М.: Стройиздат, 2004. $81 \mathrm{c}$.

4. ГОСТ 5686-2012. Грунты. Методы полевых испытаний сваями. - М., 2013.

5. Колодий Е.В. Сравнительный анализ современных методов оценки несущей способности свай (на примере сваибаретты в инженерно-геологических условиях Санкт-Петербурга). // Сборник трудов научно-технической конференции «Актуальные вопросы геотехники при решении сложных задач нового строительства и реконструкции». - СПб.: СПбГАСУ, 2010, с. 87-95.

Mangushev Rashid Abdullovich, Corresponding Member of the Russian Academy of Architecture and Construction Sciences, Professor, Doctor of Technical Sciences; Head of Geotechnical Department, Saint-Petersburg State Architecture and Construction University, Director of Scientific and Consulting Centre of Geotechnologies, Russia, Saint-Petersburg, 2-ya Krasnoarmeyskaya 4;

E-mail: ramangushev@yandex.ru.

Nadezda Sergeevna. Nikitina, $\mathrm{PhD}$, Professor, Department of "Soil Mechanics and Geotechnical", National Research Moscow State University of Civil Engineering (National Research Univer-sity), 26, Yaroslavskoe Shosse, Moscow, 129337, Russia; phone/fax: +7(495) 287-49-14;

E-mail: nsnikitina@mail.ru.

Мангушев Рашид Абдуллович, член-корреспондент PAАCH, профессор, доктор технических наук; заведующий кафедрой геотехники Санкт-Петербургского государственного архитектурно-строительного университета (СПбГАСУ), директор научно производственного консалтингового центра геотехнологий СПбГАСУ. Рос-сия, Санкт-Петербург, 2-я Красноармейская 4;

E-mail: ramangushev@yandex.ru.

Никитина Надежда Сергеевна, доцент кафедры «Механики грунтов и геотехники», Национальный исследовательский Московский государственный строительный университет, г. Москва, Россия, 129337 , Ярославское шоссе, д.26,тел./факс: +7(495) 287-49-14; E-mail: nsnikitina@mail.ru. 